\title{
Monitoring of the winter populations of cereal aphids near Wageningen, the Netherlands, in 1982/1983
}

\author{
S.C. HAND* and L. HAND* \\ Department of Theoretical Production Ecology, Agricultural University, Bornsesteeg 65, 6708 \\ $P D$ Wageningen, and \\ Department of Entomology, Agricultural University, Binnenhaven 7, 6709 PD Wageningen
}

Accepted 18 April 1986

\begin{abstract}
Cereal aphids on a wheat crop were sampled through the winter of $1982 / 1983$ using both fixed and random quadrats. Sitobion avenae overwintered successfully anholocyclically although there was a substantial decline in the population of this species. No evidence for successful anholocyclic overwintering in other aphid species was found, although Rhopalosiphum padi was seen to colonise the crop in early winter and was found until the end of December.

Eggs of R.padi on Prunus padus were observed through the winter. A steady decline in their numbers occurred. The overall survival rate of the 5385 eggs was c. $30 \%$.

Eggs of Metopolophium dirhodum on Rosa spp. were also monitored. They also showed a steady decline in numbers through the winter. The overall survival rate of the 1360 eggs was c. $34 \%$.

Egg hatch in both $R$. padi and $M$. dirhodum was closely synchronised with bud burst of their host plant. For the latter species this resulted in egg hatch starting in January.
\end{abstract}

Additional keywords: Sitobion avenae, Metopolophium dirhodum, Rhopalosiphum padi.

\section{Introduction}

The principal cereal aphid pests in Europe are Sitobion ovenae (F.), Metopolophium dirhodum (Walk.) and Rhopalosiphum padi (L.). S. avenae overwinters both anholocyclically (without eggs) and holocyclically (with eggs) on Gramineae (Hille Ris Lambers, 1939; Hand, 1982). R. padi also overwinters anholocyclically on Gramineae (e.g. George, 1974; Hand, 1982) and there is some evidence that $M$. dirhodum may do so under some circumstances e.g. 'waste' light (Prior, 1976). The latter two species also exhibit holosycly, but they da so on wcody hosts: M.dirhodum on Rosa spp. and R.padi on Prunus padus L. (Hille Ris Lambers, 1947; Rogerson, 1947). Relatively little is known about their overwintering, despite such knowledge being a prerequisite for the more effective long-term predictions of these important pests; it is during winter and spring that the numbers of aphids (and their natural enemies) which will be on the crops at the start of the epidemic, are determined.

* Present address: Southampton Common Studies Centre, Cemetery Road, The Common, Southampton SO1 2NM, England. 
The purpose of the work described here was to monitor natural populations of these three aphid species through the winter on their various hosts near Wageningen, in the centre of the Netherlands.

\section{Material and methods}

Gramineae. Wheat was selected as an example of a graminaceous host, partly because the low plant density (compared with grass sward) allowed the crop to be searched for aphids relatively easily, but also because aphids that overwinter on crops may have particular importance both in early-season development of pest populations and in the spreading of virus within the crops.

Two methods were used to monitor wheat seedlings in the centre of a crop at the Department of Field Crops, Grassland and Weed Science in Wageningen. The first method involved fixed quadrats. On 5 November 1982,75 squares of $10 \times 10 \mathrm{~cm}$ containing cereal aphids were marked out with sticks. These sites were searched at intervals (c. weekly, depending on weather conditions) until March. To avoid disturbing the aphids the searching was not exhaustive, so there were occasions when aphids apparently disappeared before subsequently being found again. This occurred more frequently as the winter progressed since mild weather allowed much tiller growth. Initially an additional area of $300 \mathrm{~cm}^{2}$ around each quadrat was monitored to assess immigration to, and emigration from, the quadrats. However, the tillering and large amount of aphid movement soon made this impossible.

The second method used random quadrats. Fifty $20 \times 20 \mathrm{~cm}$ quadrats (totalling 2 $\mathrm{m}^{2}$ ) were thrown and examined over the same field at invervals through the winter until no aphids were observed, and again at the end of the monitoring period in March.

Woody hosts. Rosa spp. Seven separate shoots of $R$. canina and R. rubiginosa and 15 twigs of $R$. rugosa, all infested with $M$. dirhodum, were selected in November and then examined at weekly intervals through the winter. The total length was $639 \mathrm{~cm}$ of twig with 215 buds. Some of these were infested by another common rose aphid species, Macrosiphum rosae (L.), although twigs were selected which did not have adults of this species on or near them. Fundatrices were collected in spring from bushes adjacent to those monitored to obtain an estimate of the percentage of eggs that were $M$. rosae. To determine whether the survival of eggs of this species was different from that of $M$. dirhodum a control experiment was set up. Five twigs with $M$. dirhodum only and two twigs with $M$. rosae only were removed from bushes (not those monitored) on 17 November and kept outdoors with the base inserted into inverted earthenware pots (for support). These control twigs were examined through the winter.

Prunus padus. Thirty bushes of P.padus (grown ornamentally in Wageningen) with a range of heights and egg densities were selected. A terminal twig on each was marked and the numbers of eggs recorded. The numbers of eggs and their condition on a total length of $1380 \mathrm{~cm}$ of twig with 529 buds were monitored at c.weekly intervals through the winter until egg hatch was complete.

Weather. The winter $(1982 / 1983)$ studied was very benign, apart from a cold spell in mid-February, during which temperatures rarely rose above $0{ }^{\circ} \mathrm{C}$. December was the 
only other month when minimum temperatures (at $10 \mathrm{~cm}$ ) fell below $0^{\circ}$ on several occasions. In the winter, rainfall was not high (being generally below $5 \mathrm{~mm}$ day ${ }^{-1}$ ), mean wind only exceeded $10 \mathrm{~m} \mathrm{~s}^{-1}$ on one day in early February and there was very little snow:

\section{Results}

Wheat. Only two aphid species were found on the wheat seedlings - S. avenae and $R$. padi. Results from the fixed quadrat sampling (Fig. 1) were difficult to interpret as aphid numbers were not only influenced by mortality and reproduction but also by immigration and emigration. That there was much movement of the aphids was evident from frequent changes in the age, colour and species of the aphids in a quadrat. The searches of the area around did not reveal many aphids, suggesting that their movements must frequently have been of distances of at least $10 \mathrm{~cm}$. The aphids were aggregated at the start of the monitoring (due to alate colonisation) and remained so throughout, despite their numbers becoming very low. The largest declines in numbers tended to occur during the more severe wind or rain conditions although this may have been coincidental. The results do show, however, that natural populations of $S$. avenae did successfully overwinter anholocyclically on the wheat crop, albeit with a low percentage of success. $R$, padi, however, did not survive beyond December in the monitored areas.

Whereas the fixed quadrats were originally sited in high aphid density areas so that part of the observed decline could be attributed to aphid movement, the random quadrats did not have this problem (since a random quadrat is equally likely to land on an area moved to by an aphid as that it has just vacated). The disadvantage, however, was that the densities of aphids quickly fell below the level that could be detected by a $2 \mathrm{~m}^{2}$ sample (Fig. 2). The final sample in March again showed that $S$. avenae had apparently successfully overwintered (probably anholocyclically), but if $R$. padi did so it was in very low numbers.

At least some of the $S$. avenae observed in the two sampling programmes were sexual morphs (both males and oviparae), but no aphid eggs were seen. Alates and

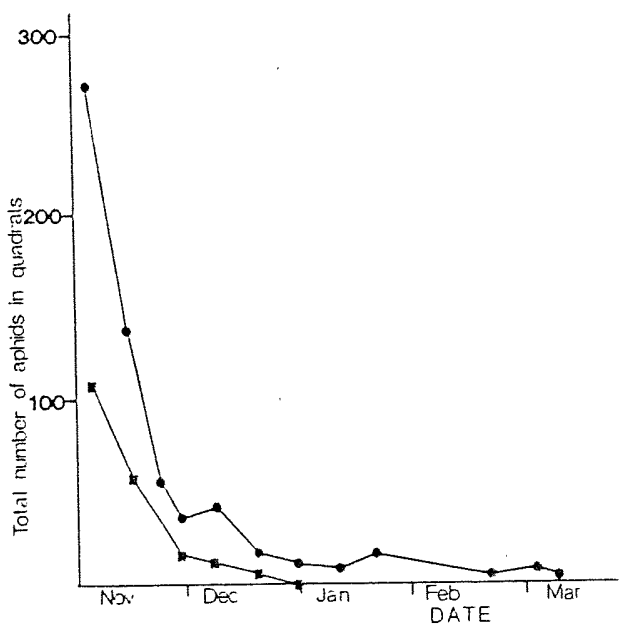

Neth. J. Pl. Path. 92 (1986)
Fig. 1. Winter populations of $S$. avenae (-) and R. padi (- ) on wheat in Wageningen $(1982 / 1983)$ in fixed quadrats (total area $\left.=0.75 \mathrm{~m}^{2}\right)$. 


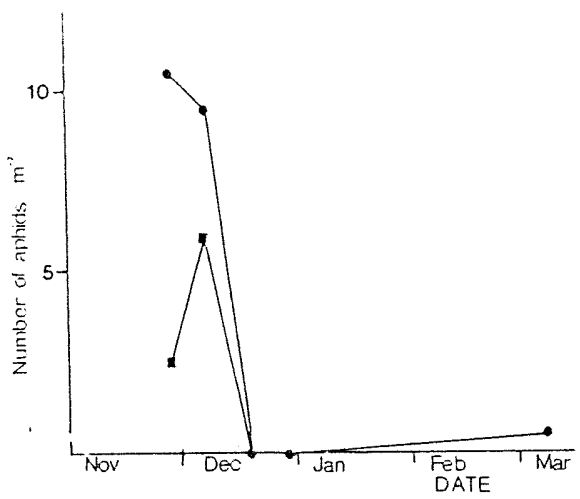

Fig. 2. Winter populations of $S$. avenae $(-\bullet)$ and $R$. padi ( ) on wheat in Wageningen $(1982 / 1983)$ in random quadrats (total area $=$ $\left.2 \mathrm{~m}^{2}\right)$.

alatiform nymphs were found in samples and brown, green and intermediate colour forms of $S$. avenae were observed.

Aphids attacked by parasites (probably mostly Aphidius rhopalosiphi/uzbekistanicus group and fungal diseases) were observed but there was no evidence for attack after December. Predators, mostly Bembidion spp. and spiders, were active throughout the winter.

Rosa spp. As the winter of $1982 / 1983$ was very mild and was preceded by a mild autumn there was a long immigration of $M$. dirhodum onto roses. This in turn led to a virtual overlap of generations - the last ovipara was observed on 27 December while the first egg hatched only eleven days later.

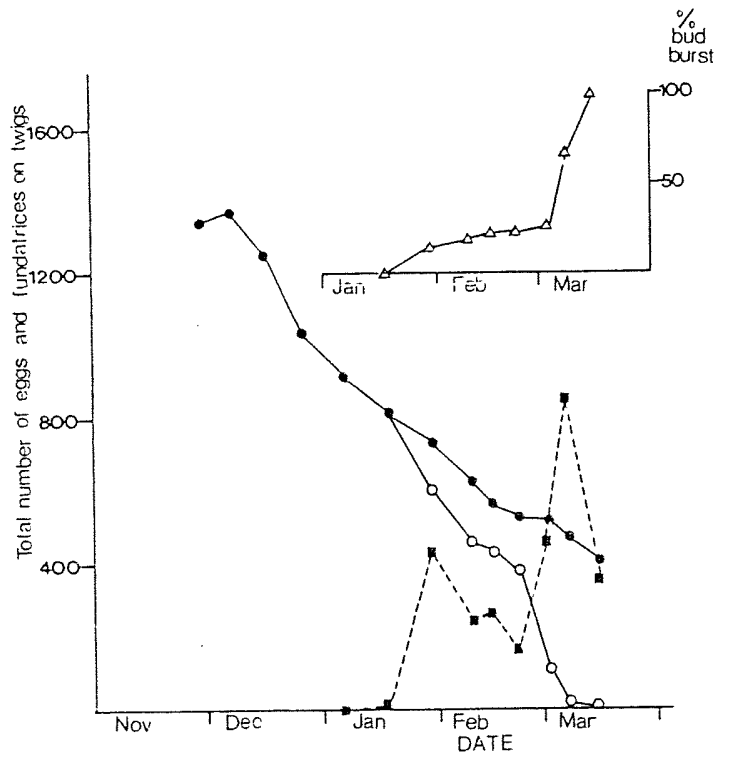

Fig. 3. M. dirhodum populations on 22 rose twigs in Wageningen during winter $1982 / 1983$ and percentage bud burst. Total number of eggs (-•); number of healthy and hatched eggs $(\sim)$; number of fundatrices ( $\longrightarrow$ ); percentage bud burst $(\Delta-\Delta)$. 
The number of eggs on the monitored twigs declined fairly steadily through December to February (Fig. 3). All eggs were apparently healthy and no predators were observed on the twigs in this period. Egg hatch began in late January, at the time bud burst started (Fig. 3). However, in the middle of February there was a slowing down of bud burst and a large decline in the numbers of live fundatrices (Fig. 3); both were almost certainly related to a cold spell in this period. After this spell was over both leaves and fundatrices continued to emerge at a rapid rate. It should be noted that many of the fundatrices counted had hatched from eggs not on the monitored parts of the bushes.

Of the 432 fundatrices collected from adjacent bushes only four $(1 \%)$ were $M$. rosae rather than $M$. dirhodum. The percentage survival of the $M$. dirhodum eggs (hatched and unhatched) on the monitored bushes between 1 December and $16 \mathrm{March}$ was c. $31 \%$. A similar value (C.34\%) was seen on the control twigs for $M$. dirhodum (starting number 648 eggs), but $M$. rosae survival was $73 \%$ (starting number 820 ). Thus it is extremely likely that virtually all the eggs monitored were $M$. dirhodum.

Predators were rarely seen on the rose bushes examined. However, some parasitized aphids were present through the winter on the monitored twigs and the parasites emerged in March.

Prumus padus. Although only one aphid species laid eggs on $P$. padus, the eggs laid were divisible into two types - shiny black healthy eggs and others which were dull green, brown or fragmented. These latter were presumable infertile or had been attack-

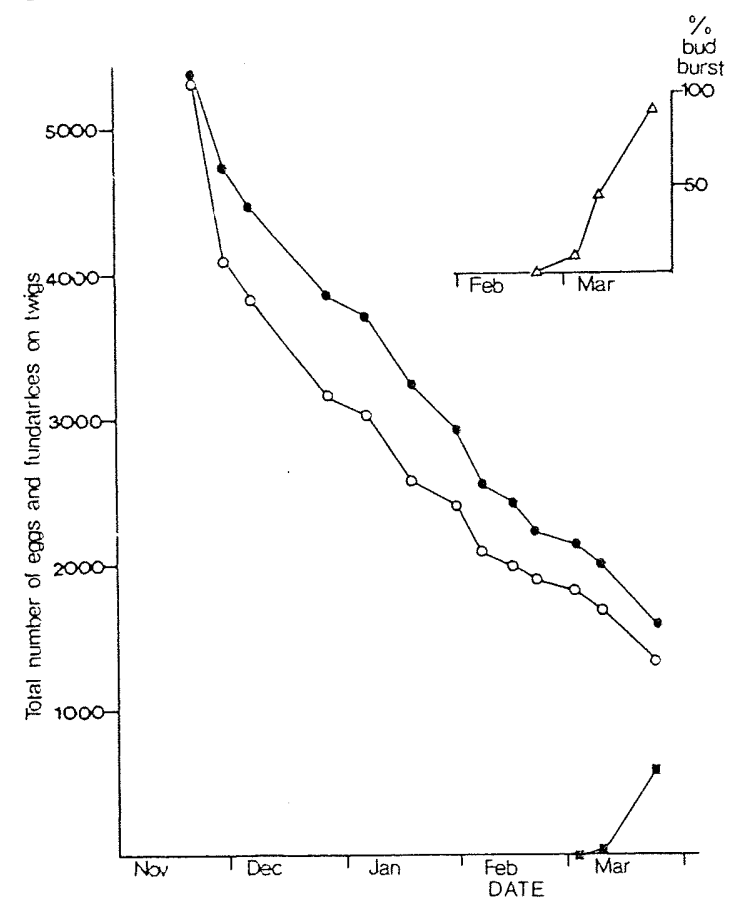

Fig. 4. R. padi populations on 30 twigs of P. padus in Wageningen during winter 1982/1983 and percentage bud burst. Total number of eggs (- $\bullet$ ); number of healthy and hatched eggs $(\circ)$ ); number of fundatrices ( $-\Delta$ ); percentage bud burst $(\Delta-$

Neth. J. Pl. Path. 92 (1986) 
ed by natural enemies. The proportion of healthy' eggs was more-or-less constant after November (Fig. 4).

As with $M$. dirhodum, the decline in numbers of $R$. padi eggs was very steady through the winter. Survival over the 18 week period was $30 \%$ (Fig. 4). The reason for the decline is not clear. The percentage survival on any twig varied from virtually zero to about $700_{0}$. However, no relationship between the survival rate and either egg density or shelter was found.

Predators were observed on the twigs: anthocorids early in the winter and spiders at intervals throughout it (although it is not known if spiders eat aphid eggs).

Egg hatch of $R$. padi was synchronised on all twigs. On 11 March no hatched eggs were observed (although a few fundatrices were seen). On 23 March 1171 of the remaining 1580 eggs had hatched (74\%); only $13 \%$ of the healthy eggs remained unhatched. Egg hatch occurred at the same time as bud burst, with a large increase in hatch being observed when the percentage of burst buds increased from $42 \%$ to $89 \%$.

\section{Discussion}

Improvement in our ability to control cereal aphids effectively and economically requires more information on both the aphids and their natural enemies. In particular, information is needed on the sources, numbers and timing of colonisers arriving on cereal crops in the spring. Knowledge of these would allow longer term predictions, more effective monitoring of the potential problem and more opportunities to apply control measures. Carrying out studies in the winter and spring is the only way to gain this necessary information.

Cereal aphids have two overwintering strategies - holocycly and anholocycly. Both have potential advantages. Holocycly involves a se: ual interchange of genetic material and the production of eggs which are resistant to low temperatures. Williams (1984) showed that the hatching success of $S$. avenae eggs was not reduced after exposure to temperatures low enough to kill over $90 \%$ of cold-hardened viviparae. Host alteration may also offer further advantages (e.g. the avoidance of predators (Way and Banks, 1968) and optimising of the nutritional status of the hosts (Dixon, 1971; 1973)). Anholocycly, on the other hand, allows an active avoidance of mortality factors such as predators and a higher population growtih through the winter and spring - not only are eggs (and males) unable to reproduce directly, but gynoparae and oviparae are both relatively unproductive (Williams, 1984). Anholocyclic individuals will continue to develop and reproduce whenever temperatures rise above a threshold of c. $3^{\circ} \mathrm{C}$ (Williams, 1984); although mean temperatures (at $1.5 \mathrm{~m}$ ) in December to February at Wageningen are frequently below $3^{\circ} \mathrm{C}$, months where the mean maximum temperature is above $3^{\circ} \mathrm{C}$ are very common. Winters when temperatures do noi allow for some development must be very rare indeed. The anholocyclic population may also have extra significance in those areas where barley yellow dwarf virus is prevalent because it may' be able to spread the virus during winter.

In a mild winter, such as the one studied, one might expect the advantages of anholocycly to outweigh those of holocycly. However, only one of the three aphid species (S. avenae) was observed to overwinter anholocyclically and that was with low success. Sexual morphs of $S$. avenae were also observed and though no eggs of this species were seen, they would be difficult to find. Assessment of the relative impor- 
tance of holocycly and anholocycly in S. avenae may only be feasible by less direct (perhaps laboratory-based) methods. For the other two species $M$. dirhodum and $R$. padi), no successful anholocycly was monitored, but holocycly on their woody primary hosts was successful. It should be noted, however, that the graminaceous habitat studied - the centre of a wheat field - may be, climatically, one of the most unfavourable for anholocyclic aphids. A higher survival rate might have been found elsewhere - for example, in a dense grass sward, near hedgerows and with snow cover. On the other hand, aphids on grass may be at a disadvantage because they may be feeding on a less nutritious host for spring population development and need to migrate onto the cereals in spring. They may also be additional mortality factors such as grazing animals (Hand, 1982) or increased numbers of natural enemies.

Concurrent with the monitoring reported in this paper, extensive field sampling was carried out (S.C. Hand and L. Hand, unpublished results). This demonstrated that $S$. avenae was present in winter on several graminaceous hosts. However, $R$. padi was more numerous in early winter on all graminaceous hosts sampled (cereals, grass crops, field-side grasses, orchard grass etc.). $M$. dirhodum was not observed on Gramineae at all during the winter.

The two species of aphid which showed successful holocyclic overwintering were M. dirhodum (on Rosa spp.) and R. padi (on P. padus). An exact survival rate for the eggs of the former was difficult to determine with accuracy as the last eggs were laid in late December but hatching started in early January and continued until mid-March. Thus the rate after December includes hatched eggs. A mortality of $66 \%$ was calculated over the 15 weeks of monitoring with the decline in numbers of eggs being fairly steady throughout the winter. The same problem did not arise for $R$. padi as egg hatch was over a short period. For this species a mortality of $70 \%$ was calculated and it occurred over 18 weeks. These mortalities are similar to those reported for $R$. padi by Leather (1980, 1981) and Leather and Lehti (1981) in England and Finland. The cause of the high mortality rate in both species is not known but there seemed similarities in the two population curves (Figs 3 and 4). $M$. rosae did not show the same high mortality even though it was kept in the same conditions as the control $M$. dirhodum eggs. The lack of large changes in mortality rate through the winter would seem to suggest that extreme weather and predators were not the main causes of mortality. $R$. padi egg survival on the different monitored twigs varied between 0 and $70 \%$. Attempts were made to find a correlation between these survival percentages and both starting egg densities (varying between 0.06 and 31.43 eggs/ $/ \mathrm{cm}$ of twig) and observed differences in shelter (some of the trees were in very exposed areas whereas others were part of the tall vegetation next to an embankment). However, no correlations were discovered (S.C. Hand and L. Hand, unpublished results). Leather (1981) obtained a greatly enhanced survival rate for $R$. padi eggs by exluding predators but as the cages used undoubtedly also excluded some rain and wind, this is not proof of the effectiveness of predators. Certainly there is a necessity for further study to determine the cause(s) of mortality. in cereal aphid eggs. Egg hatch in both $M$. dirhodum and $R$. padi was synchronised with bud burst. The timing is probably temperature-related (Hand, 1983) and reflects the fact that early hatching has both advantages and disadvantages. Early hatch ensures higher food quality and earlier reproduction leading to quicker emigration (Dixon, 1976), whereas late hatch ensures that the fundatrices have food available and encounter less extreme weather conditions (both because it is later in the spring and as

Neth. J. Pl. Fath. 92 (1986) 
there is increased shelter). The advantages and disadvantages of early hatching were clearly seen in action with $M$. dirhodum. Its ability to synchronise with its host's bud burst led to hatching in early January. However, the early fundatrices vanished during a cold spell in February (when the temperature at $10 \mathrm{~cm}$ did not rise above $0^{\circ}$ and went down to $-7^{\circ}$ ). At this time there was also a temporary slowing of bud burst. If this period had not occurred it can be presumed that the earlier fundatrices would have gone on to produce early emigrants.

The egg populations of $M$. dirhodum in Wageningen were far in excess of those observed in England by Hand and Williams (1981). This, together with the lack of observations of $M$. dirhodum anholocycly, may suggest that in the Netherlands, holocycly is even more dominant than in southern England. However, the relative amounts of Rosa in the two areas is not known. Also there may be species/variety differences.

Since only one winter was studied it is worth considering whether the implication of the results can be extended to other years. The autumn input of alatae, as recorded by the October suction trap catches at Colijnsplaat, was not particularly high for any species. However, November was very mild in the year studied so that an extended migration (when the suction trap was not operating) may have occurred. This mild weather could be a contributing factor to the virtual overlap of holocyclic generations seen for $M$. dirhodum. The weather during the winter of $1982 / 1983$ was only exceptional in that November and January were considerably warmer than normal. This would suggest that the numbers of aphids that successfully overwintered anholocyclically on Gramineae would have been enhanced. Suction trap catches at Colijnsplaat for April and early May do indeed show that alatae of both S. avenae and $R$. padi were present in higher numbers (albeit still low) and earlier than is usual. However, if a warmer winter leads to an enhanced population of overwintering aphids it is also likely to lead to an enhanced population of their natural enemies. In this work the monitoring was not designed to include assessment of natural enemies as they may be at very low densities, highly mobile, nocturnal or microscopic. However, it was noted that predators (such as the carabid Bembidion spp. and spiders) were seen often on the wheat crop (probably reflecting the mild winter) but rarely on the woody hosts (except for anthrocorids and spiders on $P$. padus in autumn). Aphids killed by fungal pathogens and parasites were observed on the wheat and roses during the winter, but there was no evidence for these enemies being active at this time.

Monitoring static eggs on the primary host in the winter is relatively simple given favourable light. However, the practical difficulties of monitoring viviparae on winter crops are enormous. Not only are they present at low densities (apparently below $0.5 / \mathrm{m}^{2}$ ) but they also move a great deal. Whether such movement is initjated by the aphids themselves, or is due to disturbance by factors such as weather, is not known. The methodological problem must be overcome (perhaps by using methods such as suction samplers (Hand, 1982)) as even low population levels on graminaceous crops are potentially very important, firstly because of the enormous area available and secondly because overwintering on them facilitates early and rapid population increase in the spring. However, such studies need to be interlinked with laboratory and detailed field studies on the effects of environmental factors such as temperature and photoperiod (e.g. C.T. Williams, in prep.; Hand and Wratten, 1985). 
Acknowledgements

This work was funded by a grant (to S.C.H.) of the International Agricultural Centre, Wageningen. We would like to thank Dr R. Rabbinge (Dept of Theoretical Production Ecology) and Dr G.W. Ankersmit (Dept of Entomology) for their help in organising the project, all those who allowed us to do work on their land and R. Rabbinge and Dr C.T. Williams for criticizing the manuscript. Thanks also go to J.D. Prinsen (Research Institute for Plant Protection) and J.W. Vaags (Dept of Physics and Meteorology') for data on suction trap catches and weather respectively.

\section{Samenvatting}

\section{Waarnemingen aan winterpopulaties van graanluizen in Wageningen}

In de winter van 1982/1983 werden de graanluizen in een tarwegewas regelmatig geteld in willekeurig en in van tevoren gekozen monstereenheden. Hoewel er een aanmerkelijke afname van de populatie van Sitobion avenae werd waargenomen, overwinterde deze soort toch anholocyclisch. Er werden geen aanwijzingen gevonden dat de andere bladluissoorten anholocyclisch overwinterden hoewel kolonies van Rhopalosiphum padi tot eind december werden waargenomen.

De gehele winter werden ejeren van $R$. padi op Prunus padi aangetroffen, de aantallen ervan namen geleidelijk af; van de 5385 getelde eieren overleefde ongeveer $30 \%$. Ook de aantallen eieren van Metopolophium dirhodum op Rosa spp. werden regelmatig vastgesteld; ook hier werd een geleidelijke afname geconstateerd. Van de oorspronkelijk getelde 1360 eieren overleefde ongeveer $34 \%$.

Het uitkomen van de eieren van $R$. padi en $M$. dirhodum viel nauw samen met het uitlopen van de knoppen van hun waardplant. Voor $M$. dirhodum betekende dit dat de eerste eieren al begin januari uitkwamen.

\section{References}

Dixon, A.F.G., 1971. The life cycle and host preferences of the bird cherry-oat aphid, Rhopalosiphum padi L., and their bearing on the theories of host alternation in aphids. Ann. appl. Biol. 68: 135-147.

Dixon, A.F.G., 1973. Biology of aphids; Institute of Biology studies in biology series, No. 44. Edward Arnold, London. 58 pp.

Dixon, A.F.G., 1976. Timing of egg hatch and viability of the sycamore aphid, Drepanosiphum platanoides (Schr.) at bud burst of sycamore, Acer pseudoplatanus L. J. Anim. Ecol. 45 593-603.

George, K.S., 1974. Damage assessment aspects of cereal aphid attack in autumn- and springsown cereals. Ann. appl. Biol. 77: 67-74.

Hand, S.C., 1982. Overwintering and dispersal of cereals aphids. Ph.D. thesis (unpub.), Southampton University

Hand, S.C., 1983. The effect of temperature and humidity on the duration of development and hatching success of the aphid, Sitobion avenae. Ent. exp. appl. 33: 220-222.

Hand, S.C. \& Williams, C.T., 1981. The overwintering of the rose-grain aphid (Metopolophium dirhodum on wild roses. In Thresh, J.M. (Ed) Pests, pathogens and vegetation, Pitman, London, pp. 307-314.

Neth. J. Pl. Path. 92 (1986) 
Hand, S.C. \& Wratten, S.D., 1985. Production of sexual morphs by the monoecious cereal aphid Silobion avenae. Ent. exp. appl. 38: 239-247.

Hille Ris Lambers. D., 1947. Contributions to a monograph of the Aphididae of Europe. II. Temminckia 4: 1-34.

Hille Ris Lambers, D., 1947. Contributions to a monograph of the Aphididae of Europe. III. Temminckia 7: 179-319.

Leather, S.R., 1980. Egg survival in the bird-cherry oat aphid, Rhopalosiphum padi. Ent. exp. appl. 27: $96-97$.

Leather, S.R., 1981. Factors affecting egg survival in the bird cherry-oat aphid, Rhopalosiphum padi. Ent. exp. appl. 30: 197-199.

Leather, S.R. \& Lehti, J.P., 1981. Abundance and survival of eggs of the bird cherry-oat aphid, Rhopalosiphum padi, in southern Finland. Annls ent. Fenn. 47: 125-130.

Prior, R.N.B., 1976. Keys to the British species of Metopolophium (Aphididae) with one new species. Syst. Ent. 1: 271-279.

Rogerson, J.P., 1947. The oat bird-cherry aphis Rhopalosiphum padi L. in comparison with $R$. crataegellum Theo. (Hemiptera, Aphididae). Bull. ent. Res. 38: 157-176.

Way, M.J. \& Banks, C.J., 1968. Population studies on the active stages of the black bean aphid Aphis fabae on its winter host Euonymus europaeus L. Ann. appl. Biol. 62: 177-197.

Williams, C.T., 1984. Overwintering and low temperature biology of cereal aphids. Ph.D. thesis, Southampton University, (unpub.). 